\title{
Attitudinal factors among elementary school teacher education students
}

\author{
Honest Ummi Kaltsum, Muhamad Taufik Hidayat \\ Department of Elementary School Teacher Education, Universitas Muhammadiyah Surakarta, Indonesia
}

\begin{tabular}{l} 
Article Info \\
\hline Article history: \\
Received Feb 18, 2020 \\
Revised Sep 17, 2020 \\
Accepted Jan 22, 2021 \\
\hline
\end{tabular}

\section{Keywords:}

Attitudinal factors

Foreign language

Learning behavior

Students' first experiences

\begin{abstract}
In second or foreign language learning, attitudinal factors were one of the key factors that determine language success and achievement. In Indonesia, foreign language (English) has been taught since elementary school, however research showed most Indonesian language learners in English showed unsatisfactorily result. This research aimed at disclosing the students' attitudinal factors in learning foreign language by exploring their first experience in learning foreign language. This qualitative study employed exploratory case study design to interview students' attitudinal factors by exploring the students past experience at first time learning foreign language. These students were from different education unit background when they were in elementary school. This study applied thematic analysis to interpret and analyze the data. The findings showed in case of attitudinal factors were categorized into three components that were cognitive, affective, and behavior. In case of cognitive and affective components, those who had good experiences felt happy in their first experience in foreign language and the vice versa. However, both were having similar learning behavior when they serve as an English teacher, they adopted particular learning behavior that was able to make students enjoy the foreign language learning.
\end{abstract}

This is an open access article under the CC BY-SA license.

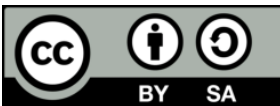

\section{Corresponding Author:}

Honest Ummi Kaltsum

Department of Elementary School Teacher Education

Universitas Muhammadiyah Surakarta

JL A. Yani Tromol Pos I Pabelan, Kartasura, Surakarta, Indonesia

Email: huk172@ums.ac.id

\section{INTRODUCTION}

Based on several previous researches [1-5], it can be said that the result of Teaching English as a foreign language in Indonesia is unsatisfactory although Indonesian students have learned English since they are in fourth grade of elementary school, even lower grade. The status policy of English in Indonesia is as a foreign language. This policy plays a crucial role in teaching and learning of foreign language. The political decision to give such kind of status to a particular language influences the social context of language learning and teaching [6]. Most of Indonesian students do not acquire good command of English after they graduate from university. The unsatisfactory results of Teaching of English as a foreign language in Indonesia were due to several points.

First is cultural context [1]. This study stated that cultural context plays a crucial role in the success of English language learning. Indonesian cultural context emphasizes respect and harmony believe and accept respectfully what subject the teachers give in the class and tend to avoid conflicts since they prefer a harmonious condition. Alwasilah [2] stated that these characters hamper the English language learning as EFL in Indonesia. 
Second is multilingual setting [5]. The students have already acquired their mother tongue in childhood and then learn Indonesian as the second language in schools, and learn English as EFL as well. A scientific theory says that the language system of the prior languages will confuse learners in acquiring a new language. This situation gives impact on their foreign language learning process.

Gultom and Supriyanti [3, 4] stated that one of the problems of English as EFL in Indonesia was the time allotment which was very limited (70 minutes per week for elementary school) and the class size was big (40 students per class). Meanwhile, a foreign language learning must be taught in small classes with high frequency of meetings and conducted on the daily basis so that the students can achieve quick results and progress [3]. The limited exposure to the targeted language in a setting of EFL addresses unsatisfactory result in English language learning in Indonesia. Meanwhile, it is noticed that the processes of foreign language learning can work without any native teachers so long as the environment provides the necessary stimuli an experience. When learners are vulnerable to lots of 'comprehensible input' in contexts of real communication, languages are learnt most effective [4].

Unfortunately, it is far from the foreign language learning in Indonesian education unit since the environment did not provide the necessary stimuli and experience. Besides, students learn English just to satisfy the school requirement so that they can graduate from their schools. They do not really feel that it is very important for their future. From the last situation, it is apparently, the students were lack of motivation on learning English and lead them to have negative attitude toward the language. When children do not have motivation, they will have bad attitude toward it $[5,7]$. In the field of acquiring foreign or second language, attitudinal factors play as one powerful role in the success of foreign or second language learning [8]. These factors drive someone's mind and trigger someone's power for the tiresome process of obtaining a second or foreign language. Regarding to students' experience, it is argued that achievement and motivation provide much influence on the perceptions of learners [9]. Supriyanti [4] reported that beliefs will give influence on someone's expectation that will shape someones' experience $[8,9]$.

Learners' previous positive or negative experiences, social, cultural, family/home background, and individual differences such as personality influence the learners' belief about their successful of foreign language [9]. The learner's belief affects their second or foreign language learning action and experience so this will also have an influence on the learners' attitude and motivation of second language (L2) and have deep impact on learning achievements and experience. Learners' attitude can be defined as a collection of feelings regarding language use and its status in the society. Fallacious beliefs about language learning might tend to create such a less effective language learning strategies and on this account it can provide less successful learners [4]. Meanwhile, belief is a key that influence teachers' views, understandings, and values. Many researchers define beliefs in many different ways. It is stated that belief is an individual judgment of the truth or falsity of a proposition, a judgment that can only be inferred from a collective understanding of what human being say, intend and do [10]. The existing body of research suggests that beliefs can be related to a number of factors such as language learning experience, gender, age, learning style, personality and academic performance differences. In this regard, beliefs about language learning are multiple parameters established points. Besides, beliefs are specific situation that may vary depending on the amount of learning experience learners have received [11]. Language learning beliefs are such a common premise of the students as language learners. They are also the characters of language learning, and factors which play role in language learning and teaching which are shaped either through personal experience or influenced by other people.

Attitudes in learning and the output of learning have strong relationship that is positive learning attitudes tend to result on both successful learning process and successful teaching process [5, 7, 12]. In regarding to second language teaching theory, this statement is supported by cognitive learning theory and sociocultural views of learning. Cognitive learning theory explains a kind of sophisticated psychological situations like motivation and other process, while sociocultural views of learning stated that social, cultural and historical influences on learning [13]. Attitudes have a very crucial role in language learning and appear to influence students' success or failure in their learning [14]. The nature of language learning are intellectual perspective, psychological and social aspects which depend primarily on the learners' motivation and attitude to learn the target language [15].

Faidah [15]; Gan, et al. [16]; Baharudin, et al. [17] presented a comprehensive body of definition of the attitude concept, attitude is classified into three correlated components namely, cognitive, affective and behavior. The cognitive component covers the beliefs, thoughts or viewpoints about the object of the attitude. It responds to the learners' beliefs in knowledge and understanding during language learning [18]. The affective aspect refers to someone's feelings and emotions towards an object, whether he/she likes or dislikes. The behavioral component is the tendency to imitate particular learning behaviors. Attitude is one factor that influence in the learning process of foreign Language learning context. The matter of learner's attitude is acknowledged as one of the most important factors that impact on learning language [8]. 
This study investigated into the concept of attitude as one of the crucial factors for success in learning a foreign language. More specifically, it investigates Elementary School Teacher Education students' (ESTES) attitudes towards learning English language, and taking into consideration the three aspects of attitude i.e., emotional, cognitive, and behavior. Attitudes, opinions and beliefs have a major influence on students' behaviors and lead to influence on their performance [19]. One who possesses positive beliefs about language learning will have more positive attitudes towards language learning. Conversely, negative beliefs may lead to low cognitive achievement, and negative attitudes [15]. An attitude can be described as an opinion and point of view on something which will influence our behavior. The behavioral component of attitude is a matter of someone behavior and reaction in particular situations. In other words, it refers to the tendency to imitate particular learning behaviors. It is stated that a positive attitude has correlation with positive behaviors toward courses of study. The learners have been seen to be more adaptive in solving the problems, more curious to obtain new information [20]. Based on these problems and several theories previously, this article aims at exploring the students' first experiences in foreign language learning and focus the discussion on attitudinal factors.

\section{RESEARCH METHOD}

The setting of this study is in residential area of Surakarta which is Surakarta, Karanganyar, Sragen, Wonogiri, Sukoharjo, Klaten, and Boyolali, Central Java, Indonesia. This is a qualitative study which employs exploratory case study design to observe and interview a specific group of students from different education unit background and apply thematic analysis to interpret and analyse the data. This study uses data sources triangulation to manage data quality. Exploratory case study attempts to answer questions typically framed by the pronoun what [21]. This exploratory case study design is elaborated to explore the students' attitudinal factors in learning foreign language by exploring their first experience in learning foreign language. The subject of this study is selected based on purposeful sampling [22] that is ten students who are from different education unit background when they were at elementary school while now, they are the students of Elementary School Teacher Education at fifth semester. The subject criteria are selected to represent the different of past learning atmosphere of English language learners in Surakarta residential.

As it had been stated by [23] that the general design of a case study is represented by a funnel, the researchers scout for possible places and people that might be the subject or the source of the data, find the study location and judge the feasibility of the site or data source for the research purposes. Creswell [24] stated that case study is a research approach to investigate thoroughly on a certain people, program, events, activity or process and the study is limited by certain place and time. The study is under qualitative design since it aims to investigate the people's attitude [25].

\section{REULTS AND DISCUSSION}

\subsection{Component of attitude}

Table 1 shows that the students are from ten different education unit or ten different elementary school in Surakarta residential which are exactly from Sragen (2 students), Sukoharjo (1 student), Karanganyar (3 students), Boyolali (1 student) and Surakarta (1 student), Klaten (1 student), and Wonogiri (1 student). As it has been written previously that definition of the attitude concept is classified into three correlated components namely, cognitive, affective and behavior, so the table description is also categorized based on that concept, namely cognitive, affective, and behaviour. The cognitive component covers the beliefs, thoughts or viewpoints about the object of the attitude. It responds to the learners' beliefs in knowledge and understanding during language learning. The affective aspect refers to someone's feelings and emotions towards an object, whether he/she likes or dislikes. The behavioral component is the tendency to imitate particular learning behaviors. 
Table 1. Component of attitude of the students

\begin{tabular}{|c|c|c|c|c|c|}
\hline No & $\begin{array}{l}\text { Name of } \\
\text { students }\end{array}$ & $\begin{array}{l}\text { Elementary } \\
\text { school (ES) }\end{array}$ & Cognitive & Affective & Behavior \\
\hline 1 & A & $\begin{array}{l}\text { Ngadirojo Lor } \\
\text { IV, Wonogiri }\end{array}$ & $\begin{array}{l}\text { She assumed that English was } \\
\text { difficult subject }\end{array}$ & Dislike & $\begin{array}{l}\text { Teacher must know well the material } \\
\text { and can create the comfortable teaching } \\
\text { situation for students }\end{array}$ \\
\hline 2 & B & $\begin{array}{l}\text { Bumiaji 2, } \\
\text { Gondang, } \\
\text { Sragen }\end{array}$ & $\begin{array}{l}\text { The teacher is less friendly by } \\
\text { forcing the students to know well } \\
\text { the English vocabularies of the } \\
\text { things around before the students } \\
\text { understand the way of writing } \\
\text { them }\end{array}$ & Dislike & $\begin{array}{l}\text { Teachers must understand good basic } \\
\text { concepts about how to teach English to } \\
\text { children so that students are able to } \\
\text { absorb learning well, use the } \\
\text { environment as a place for learning } \\
\text { English }\end{array}$ \\
\hline 3 & $\mathrm{C}$ & $\begin{array}{l}\text { Mojosongo III, } \\
\text { Surakarta }\end{array}$ & $\begin{array}{l}\text { Monotonous boring teacher, less } \\
\text { expressive }\end{array}$ & Dislike & $\begin{array}{l}\text { Teacher must be creative, expressive, } \\
\text { use fun teaching method so the students } \\
\text { do not bored }\end{array}$ \\
\hline 4 & $\mathrm{D}$ & $\begin{array}{l}\text { Wonorejo } 03, \\
\text { Karanganyar }\end{array}$ & $\begin{array}{l}\text { Students' vocabulary is poor, only } \\
\text { limited to the subjects in the class } \\
\text { and there is no practice of } \\
\text { speaking or using it }\end{array}$ & Dislike & $\begin{array}{l}\text { Give more time to students to practice } \\
\text { speaking and monitor how often } \\
\text { students speak in English by giving a } \\
\text { self -check list }\end{array}$ \\
\hline 5 & $\mathrm{E}$ & $\begin{array}{l}\text { Kalijirak } 03 \\
\text { Tasikmadu, } \\
\text { Karanganyar }\end{array}$ & $\begin{array}{l}\text { The English teacher is fierce, } \\
\text { scary, likes to give punishments }\end{array}$ & Dislike & $\begin{array}{l}\text { Teachers must understand good basic } \\
\text { concepts about how to teach English to } \\
\text { children }\end{array}$ \\
\hline 6 & $\mathrm{~F}$ & $\begin{array}{l}\text { Klumprit } 1 \\
\text { Sukoharjo }\end{array}$ & $\begin{array}{l}\text { She knows more about vocabulary } \\
\text { in English }\end{array}$ & Like & $\begin{array}{l}\text { Provide a good media to teach English } \\
\text { to Children and create fun learning }\end{array}$ \\
\hline 7 & G & $\begin{array}{l}\text { Bener } 3 \text {, } \\
\text { Sragen }\end{array}$ & $\begin{array}{l}\text { By knowing English, give more } \\
\text { knowledge }\end{array}$ & Like & $\begin{array}{l}\text { Provide a good media to teach English } \\
\text { to Children and create fun learning }\end{array}$ \\
\hline 8 & $\mathrm{H}$ & $\begin{array}{l}\text { Tarubatang } 1 \\
\text { Selo, Boyolali }\end{array}$ & $\begin{array}{l}\text { By learning English give more } \\
\text { experience }\end{array}$ & Like & $\begin{array}{l}\text { Teacher must understand the way the } \\
\text { students learn, and teacher must know } \\
\text { the material well }\end{array}$ \\
\hline 9 & I & $\begin{array}{l}\text { Matesih 03, } \\
\text { Karanganyar }\end{array}$ & $\begin{array}{l}\text { English is unique and fun } \\
\text { although difficult }\end{array}$ & Like & $\begin{array}{l}\text { Triggering students that English is fun, } \\
\text { the teacher uses appropriate learning } \\
\text { models, methods and strategies to teach } \\
\text { English to children }\end{array}$ \\
\hline 10 & $\mathrm{~J}$ & $\begin{array}{l}\text { MIM Talang, } \\
\text { Klaten }\end{array}$ & $\begin{array}{l}\text { By learning English, they get a } \\
\text { new thing }\end{array}$ & Like & $\begin{array}{l}\text { The addition of hours of learning } \\
\text { English, held a special day for English } \\
\text { activities. }\end{array}$ \\
\hline
\end{tabular}

\subsection{Cognitive and affective component of attitude}

Since the affective component refers to the individual's feelings and emotions towards an object, whether he/she likes or dislikes, the discussion of cognitive and affective component is done here as follows. Regarding to students' cognitive and affective component, it is found that those who dislike English subject are caused by three different aspects which are from the teacher, the subject, and the students. In case of the teachers, they have an experience that the teacher is less friendly by forcing the students to know well the English vocabularies of the things around before the students understand the way of writing them. Besides, monotonous boring teacher and less expressive are also found. In additional, it is found that the teacher likes giving punishment.

In case of the students, what make the students do not like English is the students' vocabulary is poor, only limited to the subjects in the class and there is no practice of speaking or using it. From the aspect of English subject itself, it is found that the students assumed that English was difficult subject to learn. Meanwhile it is also found the students who have positive feeling or emotion toward English. As such, those who feels like having English subjects when they were at elementary school are caused by several aspects which are by learning English, they obtain new vocabularies, knowledge, new experiences and new things. Although one of the students assumes that English is difficult but he or she keeps enjoying English since English is unique and fun language.

As such, experiences give influence on students' performance. This statement is supported by [26] that beliefs has a correlation with students language learning experience, learning style, personality and academic performance differences. Such kind of attitudes play a very crucial role in language learning as they would determine students' success or failure in their learning [14]. While beliefs have much influence on students' behavior, belief will also give influence on students' performance. It can be said that negative beliefs may lead to class problems, low cognitive achievement, and bad attitudes [15]. As a conclusion it is said that there is vigorous correlation between attitudes in learning and the output of learning itself that is positive learning attitudes tend to result both on successful learning process and a successful teaching process.

It has been stated previously that the cognitive component involves the beliefs, thoughts or viewpoints about the object of the attitude. Belief is defined as the student's ability in language learning, the nature of language learning, and factors which affect language learning and teaching. These beliefs are 
shaped either through personal experience or social experience which is influenced by other people. As it has been mentioned previously, learners' previous positive or negative experiences, personal and social background, and individual differences such as personality influence the learners' belief about their successful of foreign language. The learner's belief affects their second or foreign language learning action and experience so this will also have an influence on the learners' attitude and motivation of L2 and have much influence on learning achievements [27] and experience

\subsection{Behavioral component of attitude}

The behavioral component involves of attitude involves the tendency to adopt particular learning behaviors. In case of behavioral component of attitude, the interesting is all students who have good and bad experiences tend to have positive tendency to adopt particular learning behaviors. They suggest that in teaching English to children, teacher must know well the material and can create the comfortable teaching situation for students, teacher must understand good basic concepts about how to teach English to children so that students are able to absorb learning well and use the environment as a place for learning English, teacher must be creative, expressive and use fun teaching method so the students do not bored, teachers give more time to students to practice speaking and monitor how often students speak in English by giving a self -check list, teachers should provide good media to teach English to children and create fun learning, teacher must understand the way the students learn, teachers should be able to trigger students that English is fun, the teacher uses appropriate learning models, methods and strategies to teach English to children. Furthermore, the addition of hours of learning English and held a special day for English activities are also the students' tendency to adopt particular learning behaviour. This finding is supported by researches done by Abidin et al and Charoensuk which states that an attitude can be simply described as an our opinion on something which influences our behavior [28, 29]. Attitudes will determine the students success or failure in language learning [14].

The behavioral component of attitude has much concerns on the way in which one behaves and reacts in particular situations. In other words, someone tends to imitate or adopt particular learning behaviors [28]. A positive attitude can lead to learners' positive behavior toward courses of study. Such learners have been observed to be more eager to solve problems, to acquire the information and skills useful for their daily life, and to engage themselves emotionally [29]. From the discussion, it can be seen the differences of this research compared to previous research that is in case of behaviour component of attitude, it is found that students have positive component of behaviour. While $[4,30]$ reported that language learners' expectations are developed prior to their experiences, and are also influenced and shaped by their beliefs

\section{CONCLUSION}

Attitude is one factor that influence in the learning process of foreign Language learning context. This research investigates Elementary School Teacher Education students' (ESTES) attitudes towards learning English language, and taking into consideration the three aspects of attitude i.e., emotional, cognitive, and behavior. Regarding to students' cognitive and affective component, it is found that those who dislike English subject are caused by three different aspects which are from the teacher, the subject, the students. Those who like having English subjects when they were at elementary school are caused by their willing to obtain new experiences by learning English. In case of behavioral component of attitude, the interesting is all students who have good and bad experiences tend to have positive tendency to adopt particular learning behaviors.

\section{ACKNOWLEDGEMENTS}

Authors acknowledge to Kemenristekdikti Republic of Indonesia for Funding Assistance in International Networking Seminars through PP-PTS Program Kemenristekdikti 2019. This part of paper presented in 3rd World Conference on Education (WCEDU 2019) Partnership for Effective Teacher Education for Realizing the Goal of Education for All (EFA), Kuala Lumpur, November 28-29, 2019.

\section{REFERENCES}

[1] S. Suryanto, "Issues in Teaching English in a Cultural Context: a Case of Indonesia," J. English Lit. Educ. (The Teach. Learn. English as A Foreign Lang., vol. 1, no. 2, pp. 75-82, 2015.

[2] A. C. Alwasilah, "Policy on Foreign Language Education in Indonesia," International Journal of Education, vol. 7, no. 1, pp. 1-19, 2013.

[3] E. Gultom, "English Language Teaching Problems in Indonesia," in 7th International Seminar on Regional Education, 2015, vol. 3, pp. 1234-1241. 
[4] N. Supriyanti, "Challenges in Providing Trainings for English Teachers of Elementary Schools," J. Educ. Learn., vol. 6, no. 3, pp. 161-166, 2012, doi: 10.11591/edulearn.v6i3.159.

[5] M. Marcellino, "English Language Teaching in Indonesia: A Continuous Challenge in Education and Cultural Diversity," TEFLIN, vol. 19, no. 1, pp. 57-69, 2015.

[6] W. P. Rivers and E. M. Golonka, "Third language acquisition teory and practice, " in M. H. Long and C. J. Doughty, Eds. The handbook of language teaching. Oxford: Wiley-Blackwell, 2009, pp.250-266.

[7] M. Rahimi and M. Hassani, "Attitude towards EFL textbooks as a predictor of attitude towards learning english as a foreign language," in Proc. - Soc. and Behav. Sci., 2012, vol. 31, pp. 66-72, doi: 10.1016/j.sbspro.2011.12.018.

[8] S. Eshghinejad, "EFL students' attitudes toward learning english language: The case study of Kashan University students," Cogent Education, vol. 3, no. 1, pp.1-13, 2016, doi: 10.1080/2331186X.2016.1236434.

[9] X. Zuo, R. Weaver, J. MacRae, and L. Wang, "How much do emotional, behavioral, and cognitive factors actually impact college student attitudes towards English language learning? A quantitative and qualitative study," Inf., vol. 10, no. 5, 2019, doi: 10.3390/info10050166.

[10] M. Rastegar and S. S. M. Gohari, "Communication Strategies, Attitude, and Oral Output of EFL Learners: A Study of Relations,” Open J. Mod. Linguist., vol. 06, no. 05, pp. 401-419, 2016, doi: 10.4236/ojml.2016.65036.

[11] W. Littlewood and B. Yu, "First language and target language in the foreign language classroom," Lang. Teach., vol. 44, no. 1, pp. 64-77, 2011, doi: 10.1017/S0261444809990310.

[12] M. M. Alameddine, "EAP or ELF: The case of technical writing engineering students," QScience Proc., vol. 2015, no. 4, p. 47, 2015, doi: 10.5339/qproc.2015.wcee2014.47.

[13] S. Ahmed, "Attitudes towards English Language Learning among EFL Learners at UMSKAL," J. Educ. Pract., vol. 6, no. 18, pp. 6-17, 2015

[14] E. Abdolahzadeh and M. R. Nia, "Language Learning Beliefs of Iranian Learners: Examining the Role of English Language Proficiency," Procedia - Soc. Behav. Sci., 2014, vol. 98, pp. 22-28, doi: 10.1016/j.sbspro.2014.03.384.

[15] R. T. Faidah and E. Fauziati, "Exploring the Influencing Factors of Teachers' Beliefs toward the Use of Multiple Intelligences based English Teaching," Adv. Soc. Sci. Res. J., vol. 6, no. 6, pp. 137-150, 2019, doi: 10.14738/assrj.66.6653.

[16] Z. Gan, G. Humphreys, and L. Hamp-Lyons, "Understanding Successful and Unsuccessful EFL Students in Chinese Universities," Mod. Lang. J., vol. 88, no. 2, pp. 229-244, 2004, doi: 10.1111/j.0026-7902.2004.00227.x.

[17] S. N. A. Baharudin, H. M. Said, and A. Stein, "The relationship between students' attitudes and english language accomplishment: The instance of freshmen in a private learning institution," Int. J. Innov. Creat. Chang., vol. 7, no. 1, pp. 238-249, 2019.

[18] H. Ahmadi, P. Abdollahzadeh, A. Taghinezhad, and A. M. Beigi, "The Relationship between Beliefs about Language Learning, Gender, and the Use of Language Learning Strategies of Iranian Efl Learners," Mod. J. Lang. Teach. Methods, vol. 6, no. 5, pp. 31-43, 2016.

[19] Q. M. Mutar, "Attitudes of Iraqi Students toward Learning English Language," Int. J. Multicult. Multireligious Underst., vol. 6, no. 2, pp. 425-437, 2019, doi: 10.18415/ijmmu.v6i2.650.

[20] A. Kara, "The effect of a 'learning theories' unit on students' attitudes toward learning," Aust. J. Teach. Educ., vol. 34, no. 3, pp. 100-113, 2009, doi: 10.14221/ajte.2009v34n3.5.

[21] M. P. Hill, "A Qualitative, Exploratory Case Study of Self-Reported Influences Affecting the Decision of Homeless Sexual-Minority Students to Leave Home," SFA Sch. Electron. Theses Diss., 2017, [Online]. Available: https://scholarworks.sfasu.edu/etds.

[22] J. W. Creswell, Educational Research (in Bahasa). Yogyakarta: Pustaka Pelajar, 2015.

[23] S. Bogdan and R.C. Biklen, Qualitative Research for Education: An Introduction to Theory and Methods. Boston: Allyn and Bacon Inc., 1982.

[24] J. W. Creswell, Research Design, Pendekatan Kualitatif, Kuantitatif, dan Mixed. Yogyakarta: Pustaka Pelajar, 2010.

[25] B. S. Suyanto, Metode Penelitian Sosial. Jakarta: Prenadamedia Group, 2015.

[26] M. A. Al-Mekhlafi, "The Beliefs of Yemeni EFL Student Teachers about Their English Language Learning," Journal for Research Scholars and Professionals of English Language Teaching, vol. 1, no. 3, 2017.

[27] M. Bernaus, A. M. Masgoret, R. C. Gardner, and E. Reyes, "Motivation and attitudes towards learning languages in multicultural classrooms," Int. J. Multiling., vol. 1, no. 2, pp. 75-89, 2004, doi: 10.1080/14790710408668180.

[28] M. J. Z. Abidin, M. Pour-Mohammadi, and H. Alzwari, "EFL students' attitudes towards learning English language: The case of Libyan secondary school students," Asian Soc. Sci., vol. 8, no. 2, pp. 119-134, 2012, doi: $10.5539 /$ ass.v8n2p119.

[29] V. Charoensuk and D. Jaipetch, "Attitudes toward English: A study of first-year students at King Mongkut's University of Technology North Bangkok," J. Adv. Humanit. Soc. Sci., vol. 3, no. 1, pp. 42-57, 2017, doi: 10.20474/jahss-3.1.4

[30] I. Iskandar, "Putting English as Local Content Subject in Indonesian Primary Schools: Teachers' View and Its Impacts on Teaching Delivery," Proceedings The 62nd TEFLIN International Conference, 2015, pp. 758-767. 